\title{
Benefits of Bilingualism in Early Childhood: A Booster of Teaching English to Young Learners
}

\author{
Rismareni Pransiska \\ Department of Early Childhood Education, Faculty of Education, Universitas Negeri Padang \\ Corresponding e-mail: pransiskaunp2008@gmail.com
}

\begin{abstract}
For many years, bilingual program continues to receive criticism. Many experts believed that it could affect intellectual development. A number of opinions on bilingualism are often based on myths and misinterpretations, but less on scientific findings. There are numbers of myths about bilingualism and in particular about teaching children a second language early such as, language learning delay, split personality, cerebral confusion or mixing language that affects confusion. In spite of receiving criticism, there are many advantages that support bilingualism. This article is going to discuss about the definition of bilingualism, benefits of bilingualism in early childhood; cognitive advantages, social-emotional advantages, and career advantages. Furthermore, this article highlights about the phenomenon of teaching English to young learners in Indonesia in relation to benefits of being bilingual. Since English has gained the status of international lingua franca, therefore teaching English as a foreign language (afterward EFL) has become one of the major issues both to governments and individuals. Introducing English to young learner meets the benefits of bilingualism in early childhood.
\end{abstract}

Keywords: $\quad$ Bilingualism, Early Childhood, TEYL

\section{INTRODUCTION}

In Indonesia, English is still regarded as a foreign language. EFL program is only taught in English class, mostly two or three hours a week in Secondary school and High school level. EFL is not used in daily communication. Indonesian people use Bahasa or their mother tongue. In the past, teaching English in Indonesia was started from elementary school, even in many kindergartens children learned English. However, nowadays, the government omits English as a subject in Elementary school because English is considered as a difficult subject for children and it will burden them. It is also believed that teaching English in early childhood will cause bilingualism which impacts the children in a negative way.

This phenomenon is completely different with other countries. Malaysia, for instance, encourages their students to learn English as early as possible. Most of the kindergarten program provide English subject to their students. In addition, Malaysia puts English as their second language, which is widely used in school, public communication and much more. The government also has begun implementing new curriculum to help boost the English language learning as a means of encouraging the younger generation towards being better compete with the global community for nowadays and future. Furthermore, the government gives attention to ensuring students' English language proficiency through an emphasis on bilingualism (Bahasa Malaysia and English)

In the USA, bilingualism is viewed as an effort to give an opportunity to learn a second language at a young age (King \& Fogle, 2006). Many two-way bilingual education programs are growing rapidly as the explosive demand of parents who want their children being bilingual, in which both majoritylanguage and minority-language children learn two languages (Center for Applied Linguistics, 2005). It is implied that bilingualism starts from family and continued with a supported education program. Parents could start it with providing their children with video, flashcard, and books in the target language. By providing the children with plenty of 
input and interaction with the second language, bilingualism could proceed effectively.

This article is going to examine about bilingualism; separating between myth and scientific finding on bilingualism. There are many advantages of bilingualism in early childhood. Bilingualism gives benefit on cognitive, social-emotional, and academic/career advantages toward the children. It is hoped that this article helps parents and teachers avoid common misconceptions about bilingualism.

\section{BILINGUALISM}

\subsection{What is bilingualism?}

Language is a part of our lives. Most of our activities are used to communicate. People start communicates since they are babies. When a baby born, the environment influence what language she/he will use later on. At the first time, the baby acquires his/her mother tongue. Later on, she/he learns another language. Some people find it easier than others in learning a new language but most of us can do it. People who can speak two languages are considered as bilingual. Bilingualism is known as ability to use two languages in everyday life. Bilingualism is quite common and happen in many parts of the world, with perhaps one in three people being bilingual or multilingual (Wei, 2000).

\subsubsection{Fact and Myth about Bilingualism}

Naturally, children have the capacity and ability to learn more than one languages at their age. Their interest to language is quite huge. This concept has a close connection with how the children acquire language and how their language progress years by years. Actually, many factors influence them such as children age, language exposure, and social interaction. Raising bilingual children not only a challenge but also remains many questions on it. There are a number of myths about bilingualism and in particular about teaching children a second language early such as, language learning delay, split personality, cerebral confusion or mixing language that affects confusion.

In the past, bilingualism was considered as causes of slow language development. Many parents are apprehensive their children having language delay if they learn two different languages at the same period. But the fact is, speech and language delays can have many causes, mostly neurological or physiological. However, there is no strong evidence related to bilingualism. In addition, one myth about being bilingual is bilinguals have double or split personalities. The fact is, bilinguals, like no bilingual, suit their attitude to different circumstances and people. This often leads to a change of language in bilingual. This phenomenon shows that, language is a unique system. As Grosjean cited, after having reorganized themselves, the language of bilingual usually attain the linguistic level needed for the person's new life (Grosjean: 2010, p 244).

One of the biggest attention that parents have about raising children in a bilingual environment is confusion. When bilingual children mix words from two languages in the same sentence, it is often taken as evidence for confusion. This is what we call as code mixing. Actually, code mixing is a usual and natural part of bilingual development, and bilingual children surely have good motivation to do code mix (Pearson, 2008.) Instead of being a sign of confusion, code mixing can be viewed as an indication of bilingual children's creativity in language (Heinlein and Williams, 2013).

\subsubsection{Benefits of Bilingualism}

After separating fact and myth about bilingualism, now let's take a look at benefits of bilingualism. Many studies show that raising bilingual children give many benefits and advantages. Baker (2002: 12) cited that there are some advantages of being bilingual; communication, cultural, cognitive, character, curriculum and career advantages. This article is going to discuss only cognitive, socialemotional, and career/academic advantages.

\subsubsection{Cognitive benefits}

Being bilingual has connected to a number of cognitive advantages. Cognitive function refers to the mechanism of brain acquiring information. Children who are raised in bilingual environment have been found to be better competence than their monolingual peers at focusing on a task while tuning out disruption. Their capability to concentrate is better than no bilingual. The result is strongest in people who learned a second language before five and in those who are most capable in their second language. This finding implies that being bilingual from an early age significantly alters the brain's structure of the human. However, as Rueda 'work (1983) using analytical orientation in language test found that cognitive advantages may be shared by below average ability children and not just average and above ability children (Baker, 2011: 160). In addition, being bilingual makes mechanism of cognitive more flexible, which is applied to a temporal domain (efficient switching between preparatory intervals of different duration), and extends to the cognitive control processes in social 
categorization tasks (Marzecova, Bukowski, Correa, Boros, Lupianez, Wodniccka, 2013).

\subsubsection{Social-Emotional Benefits}

Bilingual children have benefit to able to make new friendship conveniently. They also can make good companionship using their second language because they can speak more than one language. This is an important skill in making new networking in this global world. They also can learn new culture through language. People say, learn a language means we learn the culture as well. As King and Mackey (2007: 8) stated that bilingual children are more simply to make friends from other languages and culture groups, both within their language school programs and. They also have positive attitude and respect about other culture and groups as well. It implies that bilingual children could be multicultural and they appreciate people from other countries and culture more.

\subsubsection{Academic and Career Benefits}

Speaking more than one language could open a big chance for children to enter their favorite university. Entering good universities need requirements for passing language tests especially English test. When they are introduced to English from early years especially in Kindergarten, it will give positive impact later on. As Jafar (2011) did in her research in Jordan, she found that kindergarten years proved to be effective for bilinguals who were to learn another language in order to engage in the mainstream community, and to learn a third language as well.

Related to vocabulary development, Thordardottir (2011) found strong relationship between amount of exposure to a language and performance. Her research is on 5-year-old Montreal children that acquiring French and English. She said that "Children having been exposed to both languages equally scored comparably to monolingual children in receptive vocabulary, but greater exposure was required to match monolingual standards in expressive vocabulary." It implies that being bilingual give impact to vocabulary development, however, this relationship was different for receptive and expressive vocabulary.

Encouraging children learn the second language also open a competitive on the job market in the future. Many workplaces and company want their employees who are proficient in multiple languages. Mastering different language is an asset for children in the future.

\section{TEACHING ENGLISH IN INDONESIA}

What about bilingualism in Indonesia? As one of the international language in the world, English should be a priority to be chosen in term of bilingualism. It needs extra effort to do it. Let us start from home. Many parents do not have competency in introducing English in their family. They also do not know how to make their children get acquaintance with English. As a result, children do not have English basic from their home. What about in school? A small portion is given to English teaching. Several years ago, English is included in elementary school curriculum, but in recent year the government omits it. They assume it will confuse and burden the children. This opinion is contrary to the concept of bilingual.

Early years is the golden moment to introduce a second language; any language. Considering the benefits of bilingualism, the government should encourage elementary school and kindergarten teachers to introduce and use English in their classes, in fun way, indeed. Being bilingual gives many advantages for children especially for their future particularly if they could master English. There are many methods and interesting media that can be used to teach English to children. It is hoped that they are motivated to know and learn English. Parents could also start it with simple English from home so that the children get acquaintance with English.

\section{CONCLUSIONS}

Bilingualism is not hazardous for children. Misunderstanding about the concept of bilingualism for years make many parents, teachers, and people do not realize the benefit of it. After separating myth and fact about bilingualism, people realize that many benefits and advantages could be gained from it. To promote successful bilingual development, both parents and teacher should work together. English as one of international language should be priory in term of bilingualism in Indonesia. It is used worldwide, therefore, placing English as the second language is a good thought in Indonesia. Introducing and teaching English in early years of our children could give many benefits for their future.

After reading this article, it is hoped that many parents and the teacher could put English as their concern to raise bilingual children in the home and school. Do not afraid to teach your children English in early childhood. And for the government, it is hoped that the English language gets bigger portion 
in the school curriculum. It could be started from kindergarten and elementary school. It gives no harmful for the children but on the contrary, it will give many benefits for their future. Many factors influence the successful of English learning, one of them is the age. It is a good idea to start English from early years without no worry about misunderstanding about bilingualism.

\section{ACKNOWLEDGEMENTS}

This work was supported by Department of Early Childhood Education, Faculty of Education, and State University of Padang. Thank you to Dewi Mulya, Ph.D for helping me correcting my English and Dr. Sarah Ohi (Deakin University), for giving ne inspiration to this writing.

\section{REFERENCES}

Baker, Colin. (2002). The care and education of young bilinguals: An introduction for Proffesionals. Great Britain: Cambrian Printers Ltd

Baker, C. (2006). Foundations of bilingual education and bilingualism (4th Ed.). Clevedon, UK: Multilingual Matters

Baker, C. (2011). Foundations of bilingual education and bilingualism (5th Ed.). Clevedon, UK: Multilingual Matters

Grosjean, François. (2010). Bilingual: life and reality. Harvard University Press

Heinlein, Krista Byersand Casey Lew Williams. (2013). Bilingualism in the Early Years: What the Science Say. LEARNing Landscapes | Vol. 7, No. 1, autumn 2013. LEARNing Landscapes | Vol. 7, No. 1, A

King, K.A. \& Fogle, L. (2006) Bilingual Parenting as Good Parenting: Parents' Perspectives on Family Language Policy for Additive Bilingualism. The International Journal of Bilingual Education and Bilingualism. Vol. 9, No. 6, 2006

King, Kendall \& Mackey, Alison. (2007). The Bilingual Edge: The Ultimate Guide to Why, When and How to teach your Child Second Langauge. USA: HarperCollins Publishers Marzecova, A., Bukowski, M., Correa, A., Boros, M., Luianez, J., \& Wodniccka, Z. 2013. Tracing the Bilingual Advantages in Cognitive Control: The Role of Flexibility in Temporal Preparation and Category Switching. Journal of Cognitive Psycology. Vol 252013 page 586-604
Pearson, B. Z. (2008). Raising a bilingual child.New York: Random House.

Thordardortir, Elin. (2011). The relationship between bilingual exposure and vocabulary development. The International Journal of Bilingulism. Desember 2011, Vol 15 No 4 page 426-445

Wei, L. (2000). Dimensions of bilingualism. In L.Wei (Ed.), The bilingualism reader (pp. 325).New York: Routledge. 